2. Уголовное право России. Части Общая и Особенная. / Под ред. А.И. Рарога. 2-е изд., перераб. и доп. - М.: Проспект, 2020.

3. Кочетков А.А. Фактическая ошибка и квалификация преступлений. Автореф. дис. ... канд. юрид. наук. - М., 1991.

4. Лунеев В.В. Уголовное право России. Общая часть: Учебник / Под ред. В.Н. Кудрявцева, В.В. Лунеева, А.В. Наумова. - М.: Юристь, 2004.

5. Электронный ресурс. Режим доступа: http://pravo.gov.ru/proxy/ips/?doc_itself=\&collection=1\&backlink=1\&nd=201124492\&page=1\&rdk=0\#I 0 (дата обращения: 20.04.2021 г.)

6. Шакин В.Б. Преодоление конкуренции уголовно-правовых норм при квалификации преступлений: Автореф. дис. ... канд. юрид. наук. - М., 2004.

7. Кириченко В.Ф. Значение ошибки по советскому уголовному праву. - М., 1952.

8. Фаткуллина М.Б. Юридическая и фактическая ошибка в уголовном праве: проблемы квалификации: Дис... канд. юр. наук. - М., 2001.

9. Безрукова Т.И. Фактическая ошибка: вопросы классификации и квалификации: Автореф. дис. ... канд. юрид. наук. - Екатеринбург, 2008.

\title{
Котилевская А.К., Шарипова Э.А. \\ К вопросу о принципах закупок товаров, работ, услуг, осуществляемых отдельными видами юридических лиц
}

doi: $10.18411 / \mathrm{lj}-06-2021-216$

\section{Аннотация}

В статье рассматриваются вопросы, связанные с основными принципами закупок товаров, работ, услуг, осуществляемых отдельными видами юридических лиц, предложены варианты поправок к Федеральному закону от 18.07.2011 № 223-Ф3 «О закупках товаров, работ, услуг отдельными видами юридических лиц».

Ключевые слова: закупки, государственные закупки, поставщик, принципы, открытость, равноправие, конкуренция.

\section{Abstract}

The article deals with issues related to the basic principles of procurement of goods, works, and services carried out by certain types of legal entities, and offers options for amendments to Federal Law № 223-FZ of 18.07.2011 «On Procurement of Goods, Works, and Services by certain types of Legal Entities».

Keywords: procurement, public procurement, supplier, principles, openness, equality, competition.

В становлении любой правовой системы ключевая роль отводится принципам. Не является исключением и система закупок. По мнению некоторых авторов, необходимость развития принципов контрактной системы не была так велика, как в настоящее время [5, с. 723].

Основные принципы закупок товаров, работ и услуг отдельными юридическими лицами отражены в статье 3 Федеральный закон от 18.07.2011 №223-Ф3 «О закупках товаров, работ, услуг отдельными видами юридических лиц» [2] (далее - Закон о закупках).

К таким основным принципам относятся:

- информационная открытость закупки;

- равноправие, справедливость, отсутствие дискриминации и необоснованных ограничений конкуренции по отношению к участникам закупки; 
- целевое и экономически эффективное расходование денежных средств на приобретение товаров, работ, услуг (с учетом при необходимости стоимости жизненного цикла закупаемой продукции) и реализация мер, направленных на сокращение издержек заказчика;

- отсутствие ограничения допуска к участию в закупке путем установления неизмеряемых требований к участникам закупки.

Необходимо отметить, что несмотря на то, что указанные выше принципы, представляющие собой основополагающие начала, должны распространятся на всех участников закупки, закон предусматривает руководства этими принципами только заказчика.

Между тем в определенных случаях к ответственности за нарушение законодательства о контрактной системе могут привлечь третье лицо [6, с. 73-76] оператора специализированной электронной площадки

Важность предусмотренных Законом о закупках принципов определена относительно рамочным способом изложения многих его статей. В случае недостатка в тексте закона точного регулирования каких-либо правоотношений, именно основные принципы будут являться главным критерием оценки тех или иных действий участников закупок. В связи с этим указанные выше принципы часто представляют собой определенную меру правовой оценки тех или иных решений участников для инспектирующих, контролирующих, а иногда и судебных органов. В дальнейшем, в процессе правоприменительной деятельности пробелы законодательства ликвидируются путем внесения изменения в закон [7, с. 155-158].

Необходимо отметить, что изложенные в Законе о закупках основные принципы тесно связаны целями этого закона и коррелируют с основными принципами, изложенными в статье 6 Федерального закона от 5 апреля 2013 г. № 44-Ф3 «О контрактной системе в сфере закупок товаров, работ, услуг для обеспечения государственных и муниципальных нужд» [3], для внесения изменений в который в последнее время внесен целый ряд законопроектов.

Принцип информационной открытости, с которого начинается перечисление основных принципов, означает в первую очередь бесплатный и открытый доступ ко всей информации о каждой закупке, а также полноту и достоверность сведений, содержащихся в этой информации. Закон о закупках предоставляет возможность абсолютно безвозмездно ознакомиться всем заинтересованным лицам с необходимой документацией, включающей в себя конкурсную документацию, информацию, содержащуюся в реестре аукционов и всю другую необходимую информацию.

На сегодняшний день принцип информационной открытости реализуется путем размещения всей, предписываемой законом информации на официальном сайте «Единая информационная система в сфере закупок» (www.zakupki.gov.ru) в сети Интернет.

Следующим основным принципом является принцип равноправия, справедливости, отсутствия дискриминации и необоснованных ограничений конкуренции по отношению к участникам закупки.

Этот принцип включает в себя четыре отдельных принципа.

Так, под принципом равноправия в Законе о закупках понимается предоставление равных возможностей для всех участников закупки на всех этапах процесса ее совершения.

Согласно принципу справедливости с одной стороны обеспечивается равенство всех участников закупки, а с другой под ним понимается требование о недопустимости предвзятости в отношении к кому-нибудь из участников закупки.

Принципы отсутствия дискриминации и необоснованных ограничений конкуренции представляют собой своеобразные дополнения к принципам равенства и справедливости, при этом необходимо отметить, что в системе нормативных актов, 
регулирующих сферу закупок в Российской Федерации, важную роль занимает Федеральный закон от 26 июля 2006 года № 135-Ф3 «О защите конкуренции» [4], в связи с чем ему должно быть уделено пристальное внимание [8, с. 12-17].

Третий принцип включает в себя такие составляющие, как требование целевого расходования и требование эффективного расходования денежных средств и является конкретизацией общего принципа эффективности закупок.

Суть это принципа заключается в том, что с одной стороны, все средства, предназначенные на конкретную закупку, должны быть потрачены именно на нее, а с другой стороны, средства должны быть потрачены эффективно, что может выражаться в частности в необходимости приобретения товаров и услуг по минимальной цене при одинаковом качестве.

Действующие нормативные акты не содержат определения «целевого использования бюджетных средств», в то время как термин «нецелевое использование бюджетных средств» содержался в статье 306.4 Бюджетного кодекса Российской Федерации (далее - БК РФ) [1]. В соответствии с этой статьей под нецелевым использованием бюджетных средств понимается их использование в любых целях, не соответствующих законодательству.

Между тем, при осуществлении закупок в соответствии с Законом о закупках тратятся, как правило, не бюджетные средства, поэтому в данном случае речь идет о расходовании денежных средств по прямому указанию распорядителя этих денежных средств, т.е. заказчика.

В соответствие со статьей 34 БК РФ под принципом эффективности использования бюджетных средств понимается достижение необходимых заданных результатов при наименьших затратах (принцип экономности). Если же стоимость расходов определена жестко, то их использование должно привести к максимально положительным результатам (принцип результативности). Представляется, что такими же принципами нужно руководствоваться при работе по Закону о закупках.

Четвертым указан принцип отсутствия ограничения допуска к участию в закупке с помощью выставления не измеряемых требований, что делает невозможным прописывать такие правила, по которым нельзя определить конкурентные предложения того или иного поставщика. Необоснованные ограничения, которые приводят к «нарушению правил государственных и муниципальных закупок в пользу отдельного исполнителя» [9, с.119] в целом сказываются на эффективности управления социальноэкономическими процессами в стране и, в конечном счете, отрицательно сказываются на благоустроенности и качестве жизни социума.

Для правильного понимания этого принципа важно точно определить понятие «неизмеряемые требования», под которыми понимается установление таких обязательных параметров, которые нельзя достоверно, точно, или хотя бы с определенной долей точности установить, измерить, посчитать или зафиксировать каким - либо иным способом в документах закупки.

Как следует из дословного толкования этого принципа в Законе о закупках, он распространяется именно на участников закупки, но не на ее объекты.

Необходимо также отметить, что умышленное установление неизмеряемых требований представляет собой один из коррупционных признаков той или иной закупки.

$$
\text { *** }
$$

1. Бюджетный кодекс Российской Федерации от 31 июля 1998 г. N 145-Ф3 // Российская газета. 12.08.1998. № 153-154.

2. Федеральный закон «О закупках товаров, работ, услуг отдельными видами юридических лиц» от 18.07.2011 N 223-Ф3. [Электронный ресурс]. - Режим доступа: http://fssprus.ru/2515217/ (дата обращения: 17.05.2021). 
3. Федеральный закон от 05.04.2013 N 44-Ф3 «О контрактной системе в сфере закупок товаров, работ, услуг для обеспечения государственных и муниципальных нужд» [Электронный ресурс]. Режим доступа: http://fssprus.ru/2515217/ (дата обращения: 05.02.2020).

4. Федеральный закон от 26 июля 2006 года № 135-Ф3 «О защите конкуренции» [Электронный pecypc]. - Режим доступа: http://ivo.garant.ru/\#/document/12148517/paragraph/234791:6 (дата обращения: 17.05.2021).

5. Булей Н.В. Принципы развития контрактной системы в строительстве // Современные проблемы науки и образования. 2015. № 1-1. С. 723.

6. Науразбаева А.А., Шарипова Э.А. К вопросу об административной ответственности за нарушение положений законодательства об обеспечении государственных и муниципальных нужд // Тенденции развития науки и образования. № 70-6. С. 73-76.

7. Shpinev Iu. S. Legislative initiatives in the law on public procurement // International Journal of Humanities and Natural Sciences. 2020. № 11-2 (50). C. 155-158.

8. Шарипов В.Г., Шарипова Э.А. К вопросу о правовых основах осуществления государственных и муниципальных закупок в Российской Федерации // Экономические исследования и разработки. 2020. № 3. C. 12-17.

9. Заика М.Л., Шарипова Э.А. Правовые основы служебного поведения государственных гражданских служащих и муниципальных служащих в субъектах Российской Федерации // Евразийский юридический журнал. 2020. № 11 (150). С. 119-121.

\section{Кошелева С.А. \\ Особенности реализации договора розничной купли-продажи в условиях развития цифровых технологий: плюсы и минусы}

Оренбургский государственный университет (Россия, Оренбург)

doi: $10.18411 / \mathrm{j}-06-2021-217$

Научный руководитель

Коноплянникова Т.В.

\section{Аннотация}

В данном научном исследовании отражены актуальность и особенности реализации договора розничной купли-продажи в сети «Интернет». В работе даётся характеристика дистанционной торговли. Проводится анализ нормативной базы, а также практики применения договора розничной купли-продажи в условиях развития цифровых технологий. В результате данного научного исследования были выделены как преимущества, так и недостатки электронной торговли.

Ключевые слова: договор, розничная купли-продажа, дистанционная торговля, цифровые технологии, "Интернет", электронная торговля.

\section{Abstract}

This scientific study reflects the relevance and features of the implementation of the contract of retail sale on the Internet. The paper describes the characteristics of distance trading. The analysis of the regulatory framework, as well as the practice of applying the contract of retail sale in the context of the development of digital technologies is carried out. As a result of this scientific study, both the advantages and disadvantages of e-commerce were highlighted.

Keywords: contract, retail purchase and sale, remote trade, digital technologies, "Internet", e-commerce.

Мы живем во времена стремительного развития цифровых технологий, в связи с чем возникает иной способ заключения договора розничной купли-продажи непосредственно в сети "Интернет", без прямого контакта с продавцом товаров. Сейчас обширно используются договоры розничной купли-продажи в интернет-магазинах. Актуальность применения подобного способа осуществления торговли определена 